\title{
PERAMPASAN BARANG BUKTI NARKOTIKA \\ (Studi Penerapan Pasal 101 ayat (1) Undang-Undang Nomor 35 tahun 2009 tentang Narkotika di Pengadilan Negeri Purbalingga) \\ Bagus Trenggono \\ (Hakim Pengadilan Negeri Purbalingga, e-mail: btrenggono@yahoo.co.id)
}

\begin{abstract}
Evidence of narcotics is forbidden and the goods that are harmful, deprivation of evidence of narcotics within the provisions of Article 101 paragraph (1) of Law No. 35 of 2009 on Narcotics is the thing that is right. Reason or rationale for the seizure of narcotics evidence to the State have legitimate reasons or technical reasons or practical. For legitimate reasons set forth in the provisions of Article 101 paragraph (1) of Law No. 35 of 2009 on Narcotics whereas technical or practical reasons provide facilities for research institutions and the pharmaceutical industry to obtain narcotics. Decisions of Judges Purbalingga stating evidence of narcotics seized for the State and for subsequently destroyed are not contrary to the provisions of Article 46 paragraph (2) Criminal Procedure Code as the legal aspects of the show in culling evidence of narcotics and as a legal ground in doing appropriation evidence of narcotics had in accordance with the provisions in Article 10 letter $b$ of the Criminal Code and Article 39 paragraph (1) of the Criminal Code.

Key words: Decisions of Judges, extermination, Narcotics, plunder
\end{abstract}

\begin{abstract}
Abstrak
Barang bukti narkotika adalah barang yang sifatnya terlarang dan berbahaya, perampasan terhadap barang bukti narkotika di dalam ketentuan Pasal 101 ayat (1) Undang-undang Nomor 35 tahun 2009 tentang Narkotika adalah hal yang sudah tepat. Alasan atau dasar pemikiran terhadap perampasan barang bukti narkotika untuk Negara mempunyai alasan yuridis maupun alasan teknis atau praktis. Alasan yuridis karena diatur di dalam ketentuan Pasal 101 ayat (1) Undang-Undang Nomor 35 tahun 2009 tentang Narkotika sedangkan alasan teknis atau praktis memberikan kemudahan bagi lembaga penelitian maupun industri farmasi untuk memperoleh narkotika. Putusan Hakim di Pengadilan Negeri Purbalingga yang menyatakan barang bukti narkotika dirampas untuk Negara dan untuk selanjutnya dimusnahkan tidak bertentangan dengan ketentuan Pasal 46 ayat (2) KUHAP sebagai aspek hukum acaranya dalam melakukan pemusnahan barang bukti narkotika dan sebagai alasan yuridis dalam melakukan perampasan barang bukti narkotika sudah sesuai dengan ketentuan di dalam Pasal 10 huruf $b$ KUHP dan Pasal 39 ayat (1) KUHP.

Kata kunci : narkotika, pemusnahan, perampasan, putusan Hakim
\end{abstract}

\section{A. Pendahuluan}

Undang-Undang Nomor 35 tahun 2009 tentang Narkotika sudah berumur 7 (tujuh) tahun sejak diundangkan, namun masih banyak permasalahan yang ditimbulkan di dalam penerapan dan pelaksanaan Undang-undang tersebut. Ada beberapa pasal didalam undang-undang ini yang dalam penerapannya akhirnya menimbulkan permasalahan baik bagi Terdakwa maupun bagi penegak hukumnya sendiri.

Permasalahan yang sering muncul adalah tentang penerapan Pasal 101 ayat (1) Undang-Undang Nomor 35 tahun 2009 tentang Narkotika khusunya mengenai barang bukti narkotika yaitu shabu-shabu, ganja, pil ekstasi, dan lain-lain, dimana dalam penerapannya 
adanya perbedaan pandangan antara

Penuntut Umum dengan Hakim mengenai penetapan status barang bukti narkotika di dalam Surat Tuntutan Penuntut Umum maupun di dalam putusan Majelis Hakim.

Pasal 101 ayat (1) UndangUndang Nomor 35 tahun 2009 tentang Narkotika berbunyi :

(1) Narkotika, Prekursor Narkotika, dan alat atau barang yang digunakan di dalam tindak pidana Narkotika dan Prekursor Narkotika atau yang menyangkut Narkotika dan Prekursor Narkotika serta hasilnya dinyatakan dirampas untuk Negara".

Di dalam praktek penerapan dan pelaksanaannya pasal ini akhirnya menimbulkan permasalahan bagi Penuntut Umum di Kejaksaan Negeri Purbalingga, khusunya mengenai barang bukti Narkotika, apabila Majelis Hakim Pengadilan Negeri Purbalingga didalam amar putusannya menentukan status barang bukti Narkotika sesuai dengan ketentuan Pasal 101 ayat (1) yaitu dirampas untuk Negara, timbul permasalahan bagi Penuntut Umum terhadap pengelolaan barang bukti narkotika tersebut. Karena dengan diputuskan status barang bukti narkotika oleh Majelis Hakim dirampas untuk Negara di dalam amar putusannya, Penuntut Umum dalam hal ini tidak bisa melakukan pemusnahan terhadap barang bukti narkotika tersebut, Penuntut Umum hanya melakukan penyimpanan dan pengelolaan terhadap barang bukti narkotika tersebut.

Makna dirampas untuk Negara karena barang bukti tersebut masih mempunyai nilai ekonomi dan barang bukti tersebut adalah kepunyaan dari Terdakwa yang diperoleh dari kejahatan atau yang sengaja dipergunakan untuk melakukan kejahatan maka Negara mempunyai hak untuk melakukan perampasan, hal ini diatur didalam Pasal 39 KUHP, nantinya oleh Penuntut Umum barang-barang bukti tersebut setelah diputus oleh Pengadilan akan dilakukan pelelangan oleh Penuntut Umum dan hasil dari pelelangan tersebut di masukkan ke kas Negara.

Maksud dan tujuan barang bukti narkotika dirampas untuk Negara di dalam Undang-undang Nomor 35 tahun 2009 tentang Narkotika adalah agar nantinya barang bukti narkotika tersebut digunakan untuk kepentingan pelayanan kesehatan dan atau untuk pengembangan ilmu pengetahuan dan teknologi bagi lembaga penelitian maupun perusahaan farmasi. Namun di dalam prakteknya baik lembaga penelitian maupun perusahaan farmasi jarang yang memanfaatkan barang bukti hasil perampasan tersebut, sehingga akhirnya menjadi beban bagi pihak Penuntut Umum di dalam penyimpanan dan pengelolaan barang bukti narkotika tersebut.

Sedikit atau banyaknya barang bukti narkotika yang ada dalam pengelolaan Penuntut Umum tetap menjadi permasalahan bagi Penuntut 
Umum di Kejaksaan Negeri Purbalingga, karena ketiadaan tempat atau ruang khusus untuk penyimpanan barang bukti narkotika di Kejaksaan Negeri Purbalingga, sehingga rentan hilang atau disalahgunakan oknum di Kejaksaan Negeri Purbalingga.

Karena permasalahan dalam pengelolaan barang bukti narkotika tersebut, maka Penuntut Umum di Kejaksaan Negeri Purbalingga setiap dalam surat tuntutannya menuntut status barang bukti narkotika dirampas untuk dimusnahkan, yang mana tidak sesuai dengan ketentuan di dalam Pasal 101 ayat (1) yang menentukan barang bukti narkotika dirampas untuk Negara, dimana Penuntut Umum mendasarkan pada ketentuan Pasal 45 ayat (4) Undang-undang Nomor 8 tahun 1981 tentang Kitab Undang-undang Hukum Acara Pidana (KUHAP).

Terhadap penentuan status barang bukti narkotika dirampas untuk dimusnahkan oleh Penuntut Umum di dalam surat tuntutannya, Hakim-hakim di Pengadilan Negeri Purbalingga memiliki argumentasi masing-masing terhadap sikap yang diambil oleh Penuntut Umum, dimana ada sebagian Hakim yang menentukan status barang bukti narkotika di dalam amar putusannya dirampas untuk dimusnahkan, mengikuti seperti apa yang dimintakan oleh Penuntut Umum di dalam surat tuntutannya yang menetapkan status barang bukti narkotika dirampas untuk dimusnahkan, sedangkan ada sebagian Hakim yang menambahkan frasa kata "dan untuk selanjutnya dimusnahkan", sehingga lengkapnya berbunyi "dirampas untuk Negara dan untuk selanjutnya dimusnahkan". Argumentasi Hakim yang melakukan penambahan frasa kata tersebut disamping tetap melaksanakan amanat dari bunyi Pasal 101 ayat (1) Undang-undang Nomor 35 tahun 2009 tentang Narkotika yang mengharuskan barang bukti narkotika dirampas untuk Negara, Hakim juga mengakomodir dari apa yang dituntut oleh Penuntut Umum di dalam Surat Tuntutannya agar barang bukti narkotika tersebut dirampas untuk dimusnahkan.

Walaupun ada perbedaan pendapat di kalangan Hakim, namun pada dasarnya mengenai penetapan status barang bukti narkotika di dalam putusan perkara tindak pidana narkotika oleh Hakim di Pengadilan Negeri Purbalingga mempunyai tujuan yang sama dimana memberikan kepastian hukum bagi Penuntut Umum terhadap status barang bukti narkotika tersebut. Sehingga berdasarkan latar belakang tersebut diatas maka penulis tertarik untuk melakukan penelitian dan penulisan hukum dengan judul "PERAMPASAN BARANG BUKTI NARKOTIKA (Studi Penerapan Pasal 101 ayat (1) Undang-Undang Nomor 35 tahun 2009 tentang Narkotika di Pengadilan Negeri Purbalingga)"

\section{B. Metode Penelitian \\ Metode Pendekatan yang digunakan dalam penelitian ini adalah}


jenis penelitian normatif. ${ }^{1}$ hukum dan sejarah hukum. Penelitian ini lebih mengedepankan penelitian terhadap sistematika hukum, dimana penelitian ini dapat dilakukan pada perundangundangan tertentu ataupun hukum tercatat.,

Tipe penelitian ini adalah Preskripsi, ${ }^{2}$ Data yang diperlukan dalam penelitian ini adalah data sekunder ditambah dengan data primer. Data sekunder dan data primer yang diperoleh akan dianalisis secara kualitatif.

\section{Pembahasan}

\section{Alasan atau dasar pemikiran barang bukti narkotika dalam perkara tindak pidana narkotika di dalam Pasal 101 ayat (1) Undang-Undang Nomor 35 tahun 2009 tentang Narkotika harus dirampas untuk Negara.}

Berdasarkan data sekunder berupa putusan dalam perkara tindak pidana narkotika yang disidangkan di Pengadilan Negeri Purbalingga dari tahun 2015 sampai dengan tahun 2017, Pengadilan Negeri Purbalingga telah menerima dan memutus sebanyak 26 (dua puluh enam) perkara tindak pidana narkotika.

1 Soerjono Soekanto dan Sri Mamudji,2012, Penelitian Hukum Normatif, Raja Grafindo Persada, Jakarta, hal. 14.

2 Peter Mahmud Marzuki, 2005, Penelitian Hukum, Kencana Prenada Media Group, Jakarta, hal. 37
Seluruh berkas perkara tindak pidana narkotika yang diperiksa oleh Majelis Hakim di Pengadilan Negeri Purbalingga menyangkut barang bukti narkotika pada pokoknya seluruhnya dinyatakan dirampas untuk dimusnahkan, dimana ada Majelis Hakim yang menetapkan barang bukti narkotika dinyatakan dirampas untuk dimusnahkan dan ada Majelis Hakim yang menetapkan barang bukti narkotika terlebih dahulu melaksanakan ketentuan di dalam Pasal 101 ayat (1) Undang-undang Nomor 35 tahun 2009 tentang Narkotika dengan menambahkan frasa kata "dan untuk selanjutnya dimusnahkan" sehingga di dalam putusannya menetapkan barang bukti narkotika dinyatakan dirampas untuk Negara dan untuk selanjutnya dimusnahkan.

Untuk mengetahui alasan atau dasar pemikiran barang bukti narkotika dalam perkara tindak pidana narkotika di dalam ketentuan Pasal 101 ayat (1) Undang-Undang Nomor 35 tahun 2009 tentang Narkotika harus dirampas untuk Negara, diperoleh dari data primer berupa hasil wawancara dengan Hakim-Hakim Pengadilan Negeri Purbalingga yang menyidangkan perkara tindak pidana narkotika dan data sekunder berupa Undang-undang, tulisan atau pendapat para pakar dan sebagainya. 
Berdasarkan data primer tersebut, Majelis Hakim Pengadilan Negeri Purbalingga mempunyai pendapat yang sama bahwa oleh karena di dalam prakteknya selama ini tidak ada permintaan dari lembaga penelitian maupun industri farmasi terhadap barang bukti narkotika yang ada dalam penyimpanan dan pengelolaan Penuntut Umum dan karena sifat dari barang bukti narkotika adalah barang yang berbahaya, sehingga Majelis Hakim Pengadilan Negeri Purbalingga dalam hal ini tetap melaksanakan apa yang diatur di dalam Pasal 101 ayat (1) Undangundang Nomor 35 tahun 2009 tentang Narkotika, namun juga tetap mengakomodir apa yang menjadi permintaan penuntut umum di dalam surat tuntutannya dimana di dalam putusan Majelis Hakim menyatakan barang bukti narkotika dirampas untuk Negara dan untuk selanjutnya dimusnahkan.

Mengenai alasan barang
bukti narkotika dalam perkara
tindak pidana narkotika di dalam
Pasal 101 ayat (1) Undang-Undang Nomor 35 tahun 2009 tentang Narkotika harus dirampas untuk Negara dapat diuraikan sebagai berikut :

Pengertian dirampas atau perampasan berasal dari kata rampas. Kata rampas menurut kamus umum bahasa Indonesia artinya merebut, mengambil dengan paksa ${ }^{3}$. Kata "rampas" dalam Pasal 45, 46, 194, 205, 273 KUHAP selalu diikuti dengan kata "untuk negara".

Dengan demikian menurut penulis pengertian perampasan adalah peralihan kepemilikan secara paksa terhadap suatu benda dari pemiliknya semula menjadi milik Negara yang dinyatakan oleh Hakim baik dalam pertimbangan hukum maupun dalam amar putusan.

Barang rampasan adalah barang-barang atau benda-benda baik bergerak maupun tak bergerak atau alat-alat yang dipergunakan dan/atau diperoleh diperoleh dari tindak pidana, yang kemudian dirampas untuk kepentingan Negara berdasarkan putusan pengadilan. Putusan pengadilan tentang perampasan terhadap barang-barang/benda-benda

dan/atau alat-alat yang dipergunakan dan/atau diperoleh dari tindak pidana, hakikatnya merupakan sanksi tambahan sebagaimana diatur Pasal 10 huruf b angka 2 Kitab Undang-Undang Hukum Pidana. ${ }^{4}$

Menurut penjelasan Pasal 45 ayat (4) KUHAP, yang dimaksud dengan benda yang dirampas

3 W.J.S. Poerwadarminta, Kamus Umum Bahasa Indonesia, Balai Pustaka, Jakarta, hal. 943.

${ }^{4}$ J.C.T Simorangkir, 2004, Kamus

Hukum, op.cit, hal. 126 
untuk Negara" adalah benda yang harus diserahkan kepada Departemen yang bersangkutan sesuai dengan ketentuan perundang-undangan yang berlaku. Misalnya barang hasil selundupan yang ditetapkan dirampas untuk Negara, berarti hasil penjualan barang itu diserahkan kepada Departemen Keuangan jika barang itu dilelang atau jika barang yang dirampas untuk Negara berupa obat-obat, diserahkan ke Departemen Kesehatan. ${ }^{5}$

Dari uraian-uraian diatas diperoleh kesimpulan apa yang menjadi alasan atau dasar pemikiran barang bukti narkotika dalam perkara tindak pidana narkotika di dalam Pasal 101 ayat (1) Undang-Undang Nomor 35 tahun 2009 tentang Narkotika harus dirampas untuk Negara sebagai berikut :

1. Alasan yuridis. Pasal 101 ayat (1) Undangundang Nomor 35 tahun 2009 tentang Narkotika memberikan dasar bagi Hakim untuk melakukan perampasan terhadap barang bukti narkotika dimana barang bukti narkotika dinyatakan di dalam putusannya oleh Hakim dirampas untuk Negara.

2. Alasan teknis atau praktis. Mengingat sifat dan efek dari narkotika yang merupakan bahan yang berbahaya akan tetapi narkotika di sisi yang lain merupakan obat atau bahan yang bermanfaat di

5 Yahya Harahap, 2005, Pembahasan Permasalahan dan Penerapan KUHAP, Sinar Grafika, Jakarta, hal. 369 $\begin{array}{lr}\text { bidang pengobatan atau } & \text { dan } \\ \text { pelayanan kesehatan } & \text { ilmu } \\ \text { pengembangan } & \text { jika } \\ \text { pengetahuan sehingga } & \text { jirampas untuk Negara dari } \\ \text { sisi teknis maupun sisi } \\ \text { kepraktisan akan memberikan } \\ \text { kemudahan bagi lembaga ilmu } \\ \text { pengetahuan maupun industri } \\ \text { farmasi untuk mendapatkan } \\ \text { narkotika tersebut dan } \\ \text { tentunya dengan biaya yang } \\ \text { relatif lebih murah } \\ \text { dibandingkan membeli dari } \\ \text { pasar. }\end{array}$

Mengenai apa yang menjadi alasan atau dasar pemikiran barang bukti narkotika di dalam ketentuan Pasal 101 ayat (1) Undang-Undang Nomor 35 tahun 2009 tentang Narkotika harus dirampas untuk Negara dapat juga dilihat di dalam konsideran Undang-undangnya, dimana di dalam konsideran UndangUndang Nomor 35 tahun 2009 tentang Narkotika huruf $\mathrm{c}$ disebutkan bahwa Narkotika di satu sisi merupakan obat atau bahan yang bermanfaat di bidang pengobatan atau pelayanan kesehatan dan pengembangan ilmu pengetahuan dan di sisi lain dapat pula menimbulkan ketergantungan yang sangat merugikan apabila disalahgunakan atau digunakan tanpa pengendalian dan pengawasan yang ketat dan saksama.

$$
\text { Maksud dan tujuan }
$$
pembuat Undang-undang Nomor 35 tahun 2009 tentang Narkotika baik dilihat dari konsideran maupun di dalam Pasal-Pasal yang telah 
diuraikan diatas bahwa narkotika

digunakan untuk kepentingan

pelayanan kesehatan,

pengembangan ilmu pengetahuan

dan teknologi, sesuai dengan

tujuan dari undang-undang

narkotika tersebut bahwa narkotika

digunakan untuk kepentingan

pelayanan kesehatan dan atau

untuk pengembangan ilmu

pengetahuan dan teknologi bagi

lembaga penelitian maupun

perusahaan farmasi, akan tetapi di

dalam prakteknya penuntut umum

keberatan terhadap putusan Majelis

Hakim yang menyatakan barang

bukti narkotika dirampas untuk

Negara, alasan dari Penuntut

Umum, Penuntut Umum tidak

memiliki tempat atau ruangan

khusus untuk penyimpanan dan pengelolaan barang bukti narkotika, disamping itu Penuntut Umum khawatir akan diselewengkan atau disalahgunakan oleh oknum di Kejaksaan jika barang bukti narkotika ada dalam pengelolaan Penuntut Umum dan selama ini tidak pernah ada permintaan dari lembaga penelitian ataupun dari industri farmasi terhadap barang bukti narkotika yang ada di Penuntut Umum, oleh karena barang bukti narkotika adalah barang yang berbahaya dan mengakomodir keberatan dari Penuntut Umum, Majelis Hakim bersikap tetap melaksanakan apa yang diperintahkan di dalam pasal
101 ayat (1) UU Nomor 35 tahun 2009 tentang Narkotika akan tetapi juga mengakomodir apa yang menjadi permintaan dari Penuntut Umum di dalam surat tuntutannya, sehingga Majelis Hakim di Pengadilan Negeri Purbalingga menyatakan barang bukti narkotika dinyatakan dirampas untuk Negara dan untuk selanjutnya dimusnahkan.

2.Alasan atau dasar pemikiran penambahan frasa kata "dan untuk selanjutnya dimusnahkan" oleh Hakim dalam memutus perkara tindak pidana narkotika di Pengadilan Negeri Purbalingga tidak bertentangan dengan Pasal 101 ayat (1) Undang-Undang Nomor 35 tahun 2009 tentang Narkotika.

Berdasarkan data sekunder berupa putusan dalam perkara tindak pidana narkotika yang disidangkan di Pengadilan Negeri Purbalingga dari tahun 2015 sampai dengan tahun 2017, Pengadilan Negeri Purbalingga telah menerima dan memutus sebanyak 26 (dua puluh enam) berkas perkara tindak pidana narkotika. Seluruh berkas perkara tindak pidana narkotika yang diperiksa oleh Pengadilan Negeri Purbalingga tersebut, ada bebarapa putusan mengenai status barang bukti narkotika dinyatakan dirampas untuk Negara dan untuk selanjutnya dimusnahkan dimana Majelis Hakim tetap melaksanakan apa yang tertulis di dalam Pasal 101 ayat (1) UU Nomor 
35 tahun 2009 tentang Narkotika namun dengan menambahkan frasa kata "dan untuk selanjutnya dimusnahkan" dan ada beberapa putusan dari Majelis Hakim menyatakan barang bukti narkotika dirampas untuk dimusnahkan sesuai dengan tuntutan Penuntut Umum.

$$
\text { Putusan Majelis Hakim }
$$

Pengadilan Negeri Purbalingga menyatakan barang bukti narkotika dirampas untuk Negara dan untuk selanjutnya dimusnahkan.Dimana Majelis Hakim menambahkan frasa kata "dan untuk selanjutnya dimusnahkan". Hal tersebut tentunya tidak sesuai dengan apa yang telah diatur di dalam ketentuan Pasal 101 ayat (1) Undang-undang Nomor 35 tahun 2009 tentang Narkotika mengenai barang bukti narkotika. Apakah penambahan frasa kata "dan untuk selanjutnya dimusnahkan" oleh Hakim dalam memutus perkara tindak pidana narkotika di Pengadilan Negeri Purbalingga tidak bertentangan dengan Pasal 101 ayat (1) UndangUndang Nomor 35 tahun 2009 tentang Narkotika?

$$
\text { Di dalam Undang-undang }
$$

Nomor 8 tahun 1981 tentang Hukum Acara Pidana juga diatur mengenai perampasan dan pemusnahan barang bukti di dalam Pasal 45 ayat (4) dan Pasal 46 ayat (2).

Kitab Undang-undang Hukum Pidana juga mengatur tentang perampasan barang bukti di dalam Pasal 39 ayat 1 KUHP.
Bahwa selanjutnya Penulis akan membahas dan menganalisa mengenai permasalahan Apakah penambahan frasa kata "dan untuk selanjutnya dimusnahkan" oleh Hakim dalam memutus perkara tindak pidana narkotika di Pengadilan Negeri Purbalingga tidak bertentangan dengan Pasal 101 ayat (1) UndangUndang Nomor 35 tahun 2009 tentang Narkotika, Penulis akan menggunakan teori penemuan hukum.

Pembahasan akan dilakukan dengan menggunakan metode-metode yang disediakan dalam teori Penemuan Hukum.

Seperti diketahui bahwa hukum atau peraturan perundang-undangan itu tidak lengkap dan tidak selalu jelas dan tidak mungkin lengkap selengkaplengkapnya atau jelas sejelas-jelasnya. Oleh karena itu perlu dilengkapi atau dijelaskan dengan mencari atau menemukan hukumnya.

Mengenai apa yang dimaksud dengan penemuan hukum, Soedikno ${ }^{6}$, memberikan pendapatnya :

"Penemuan hukum pada dasarnya merupakan kegiatan praktek hukum (hakim, pembentuk undangundang, dan sebagainya). Akan tetapi penemuan hukum tidak dapat dipisahkan dari ilmu (teori) hukum. Kalaupun secara historis teoritis praktek hukum itu lahirnya lebih dahulu dari ilmu hukum, tetapi dalam perkembangannya praktek hukum memerlukan landasan teoritis dari ilmu hukum, sebaliknya ilmu hukum memerlukan

${ }^{6}$ Soedikno Mertokusumo, 2006, Penemuan Hukum suatu Pengantar,Liberty, Yogyakarta, hal. 1. 
materialnya dari praktek hukum. Jadi dalam prakteknya, praktek hukum dan ilmu hukum itu saling memerlukan satu sama lain".

Lebih lanjut dikemukakan oleh Soedikno ${ }^{7}$ bahwa Undang-undang sebagaimana norma pada umumnya, berfungsi untuk melindungi kepentingan manusia, sehingga harus dilaksanakan atau ditegakkan. Undang-undang harus diketahui oleh umum, tersebar luas dan harus jelas. Kejelasan undang-undang sangatlah penting. Oleh karena itu setiap undang-undang selalu dilengkapi dengan penjelasan yang dimuat dalam Tambahan Lembaran Negara. Sekalipun nama dan maksudnya sebagai penjelasan, namun sering terjadi penjelasan tersebut, tidak juga memberi kejelasan karena hanya dinyatakan cukup jelas, padahal teks undang-undang tidak jelas dan masih memerlukan penjelasan. Mungkin saja pembentuk undang-undang bermaksud hendak memberi kebebasan yang lebih besar kepada hakim.

Hal yang sama dikemukakan oleh Bagir Manan ${ }^{8}$ :

"Dalam hukum in concreto maupun in abstarcto, ternyata hukum tidak pernah lengkap, tidak pernah sempurna. Secara abstracto tidak pernah ada kemampuan pembentuk hukum

${ }^{7}$ Soedikno Mertokusumo, 2008, Mengenal Hukum, Liberty, Yogyakarta, hal. 168.

${ }^{8}$ Bagir Manan, 2004, Hukum Positif Indonesia (Suatu Kajian Teoritik), FH UII Press, Yogyakarta, hal. vi (tertulis dan tidak tertulis) yang dapat membuat kaidah yang mencakup seluruh tingkah laku manusia, seluruh kebutuhan individu maupun masyarakat. Sedangkan secara concreto, tidak ada dua peristiwa hukum yang benar-benar serupa, sehingga tidak selalu putusan hakim dapat disandarkan pada bunyi ketentuan yang ada atau mengandalkan putusan terdahulu. Karena hukum disatu pihak tidak pernah lengkap, dipihak lain ada berbagai peristiwa hukum yang harus diselesaikan (secara hukum), maka lahir metode penerapan hukum agar hukum yang tidak lengkap atau tidak jelas, dapat diterapkan secara wajar, tepat dan benar terhadap peristiwa konkrit yang terjadi. Dalam penerapan hukum, dikenal adanya suatu penemuan hukum (rechtsvinding atau legal finding).

Lebih lanjut dikemukakan oleh Bagir Manan ${ }^{9}$, bahwa penemuan hukum diperlukan dalam rangka memecahkan atau menyelesaikan suatu persoalan hukum berdasarkan atau secara hukum. Hukum sebagai dasar yaitu hukum yang berlaku atau hukum positif. Dalam hal hukum positif mengatur suau peristiwa hukum dengan jelas, maka penemuan hukum adalah mempertemukan peristiwa hukum yang konkrit dengan aturan hukum yang ada. Tetapi apabila aturan hukum tidak ada atau tidak jelas, atau

\footnotetext{
${ }^{9}$ Ibid, hal. vii-viii.
} 
simpang siur, penemuan hukum harus diartikan sebagai upaya hakim menemukan pengertian-pengertian hukum yang ada atau menggali berbagai bahan hukum yang bersumber dari berbagai kenyataan, kesadaran atau pandangan hukum atau teori-teori hukum yang tersedia, sehingga suatu peristiwa hukum konkrit dapat dipecahkan dan diselesaikan secara wajar, tepat dan benar.

Demikian pula pendapat Peter Mahmud Marzuki ${ }^{10}$ mengenai apa yang dimaksud dengan penemuan hukum ;

Terlepas dari tidak wajibnya mengikuti preseden, diacunya yurisprudensi kuat bagi penyelesaian sengketa serupa menunjukkan bahwa tugas hakim bukan sekadar menerapkan undangundang. Melalui putusannya yang menjadi yurisprudensi kuat, hakim juga membuat hukum. Hal itu dalam praktik penyelesaian sengketa tidak dapat dihindari manakala terminologi yang digunakan oleh undang-undang tidak jelas, undang-undang tidak mengatur masalah yang dihadapi atau undangundang yang ada bertentangan dengan situasi yang dihadapi. Oleh karena itulah hakim dalam hal ini laiu melakukan pembentukan hukum (rechtsvorming), analogi (rechtsanalogie), penghalusan hukum (rechtsverfijning) atau penafsiran (interpretatie). Kegiatan-kegiatan

10 Peter Mahmud Marzuki, Pengantar Ilmu Hukum, op. cit., hal. 282 semacam itu dalam sistem hukum kontinental disebut sebagai penemuan hukum (rechtsvinding).

Dalam melakukan penemuan hukum, dikenal adanya sumber hukum. Menurut Soedikno, ${ }^{11}$ sumber penemuan hukum tidak lain adalah sumber atau tempat terutama bagi hakim untuk dapat menemukan hukumnya. Sumber utama penemuan hukum adalah peraturan perundangundangan, kemudian hukum kebiasaan, yurisprudensi, perjanjian internasional, barulah doktrin. Oleh karenanya apabila terdapat konflik dua sumber, maka sumber hukum yang tertinggi akan melumpuhkan sumber hukum yang lebih rendah.

Menurut Soedikno, ${ }^{12}$ dalam ajaran penemuan hukum, peraturan perundang-undangan diprioritaskan dari sumber-sumber penemuan hukum yang lain. Apabila hendak mencari hukumnya arti suatu kata, maka dicarilah terlebih dahulu dalam peraturan perundang-undangan, karena peraturan perundangundangan bersifat otentik dan berbentuk tertulis yang lebih menjamin kepastian hukum.

Hukum adalah suatu sistem, maka untuk memahami suatu pasal dalam undang-undang atau untuk memahami suatu undang-undang, sering harus dibaca juga pasal-pasal

\footnotetext{
${ }^{11}$ Soedikno Mertokusumo,
} Penemuan Hukum Sebuah Pengantar, op.cit, hal. 48.

${ }^{12}$ Ibid, hal. 48. 
yang lain dalam undang-undang itu atau peraturan perundang-undangan yang lain. Undang-undang tidak boleh diinterpretasikan bertentangan dengan undang-undang itu sendiri (contra legem).

Ada dua metode utama yang dipergunakan dalam penemuan hukum yaitu metode penafsiran dan metode konstruksi hukum. Metode penafsiran dipergunakan manakala ada aturannya, namun tidak jelas untuk diterapkan, sedangkan metode konstruksi hukum dipergunakan manakala tidak ada aturannya sama sekali di satu sisi, dan disisi lain persoalan tersebut harus ditemukan hukumnya.

Dalam metode penafsiran, dikenal beberapa macam penafsiran, diantaranya yaitu penafsiran menurut tata bahasa/gramatika, penafsiran sistematis, penafsiran sejarah dan penafsiran teleologis. Selain penafsiran-penafsiran tersebut, dalam beberapa literatur disebutkan masih adanya beberapa penafsiran yang lain.

Pada hakekatnya interpretasi undang-undang menurut interpretasi gramatika adalah cara interpretasi permulaan saja. interpretasi gramatika adalah cara yang selalu dipakai pada permulaan usaha interpretasi, yang selanjutnya interpretasi gramatika itu dengan sendirinya membimbing hakim ke arah cara-cara interpretasi yang lain, yaitu interpretasi sistematis.

Metode penafsiran sistematis atau logis adalah menafsirkan peraturan perundang-undangan dengan menghubungkannya dengan peraturan hukum atau undang-undang lain atau dengan keseluruhan sistem hukum. Dalam metode penafsiran ini, hukum dilihat sebagai satu kesatuan yang utuh, tidak merupakan bagian yang berdiri sendiri tetapi merupakan bagian dari satu sistem. Interpretasi gramatikal merupakan interpretasi atau penjelasan undang-undang yang paling sederhana dibandingkan dengan metode interpretasi yang lain. $^{13}$

Penafsiran sistematis dilakukan dengan meninjau susunan yang berhubungan dengan pasal-pasal lainnya baik dalam undang-undang yang sama maupun dengan undangundang yang lain. ${ }^{14}$

Penafsiran sistematis bertolak dari prinsip, hukum adalah sebuah sistem. Untuk menemukan arti atau pengertian suatu norma atau istilah, dilakukan dengan cara menghubungkan suatu ketentuan dengan ketentuan-ketentuan lain, baik dalam peraturan perundang-undangan yang sama maupun dengan peraturan perundang-undangan atau kaidah hukum lain. ${ }^{15}$

${ }^{13}$ Philipus M. Hadjon dan Tatiek Sri Djatmiati, 2014, Argumentasi Hukum, Gadjah Mada University Press, Yogyakarta, hal. 61-87.

${ }^{14}$ C.S.T. Kansil, 2002, Pengantar Ilmu Hukum, Balai Pustaka, Jakarta, hal. 3641

15 Peter Mahmud Marzuki, Pengantar Ilmu Hukum, op.cit, hal. 72 


\begin{abstract}
Dalam membahas dan menganalisa permasalahan kedua dalam tulisan ini, penulis akan menggunakan metode penafsiran sistematis.

Berdasarkan pendapat para narasumber sebagaimana dikemukakan di atas, maka penambahan frasa kata "dan untuk selanjutnya dimusnahkan" oleh Hakim dalam memutus perkara tindak pidana narkotika di Pengadilan Negeri Purbalingga tidak bertentangan dengan Pasal 101 ayat (1) UndangUndang Nomor 35 tahun 2009 tentang Narkotika. Pendapat para narasumber tersebut apabila dikaitkan dengan pendapat para ahli mengenai penggunaan penafsiran sistematis dalam penemuan hukum, maka penggunaan penafsiran sistematis dalam penentuan status barang bukti di dalam putusan perkara tindak pidana narkotika di Pengadilan Negeri Purbalingga adalah sudah tepat. Dimana Hakim juga telah mengakomodir dari apa yang dituntut oleh Penuntut Umum di dalam Surat Tuntutannya agar barang bukti narkotika tersebut dirampas untuk dimusnahkan.
\end{abstract}

Pasal 101 ayat (1) Undangundang Nomor 35 tahun 2009 tentang Narkotika berikut penjelasannya, berdasarkan penelitian Penulis penjelasan Pasal 101 ayat (1) Undangundang Nomor 35 tahun 2009 tentang Narkotika secara jelas menetapkan barang bukti narkotika dirampas untuk
Negara dan selama ini tidak ada satu aturan baik itu SEMA maupun PERMA yang dikeluarkan oleh Mahkamah Agung mengenai penentuan status barang bukti narkotika.

Pasal 101 ayat (1) Undangundang Nomor 35 tahun 2009 tentang Narkotika di dalam pelaksanaannya menimbulkan permasalahan bagi Penuntut Umum, dimana Penuntut Umum kesulitan di dalam pengelolaan maupun penyimpanan barang bukti narkotika tersebut, sampai akhirnya di dalam setiap surat tuntutan dari Penuntut Umum tidak pernah berpedoman kepada ketentuan Pasal 101 ayat (1) tersebut akan tetapi Penuntut Umum berpedoman kepada ketentuan Pasal 45 ayat (4) KUHAP yang menyatakan barang bukti narkotika dirampas untuk dimusnahkan, menurut penulis apa yang telah dilakukan oleh Majelis Hakim di Pengadilan Negeri Purbalingga dengan menambahkan frasa kata "dan untuk selanjutnya dimusnahkan" sangatlah tepat dimana Majelis Hakim tetap melaksanakan apa yang menjadi ketentuan di dalam Pasal 101 ayat (1) Undang-undang Nomor 35 tahun 2009 tentang Narkotika namun juga tetap mengakomodir apa yang menjadi tuntutan Penuntut Umum terhadap barang bukti narkotika tersebut.

Penafsiran sistematis yaitu menafsirkan peraturan perundangundangan dengan menghubungkannya dengan peraturan 
hukum atau undang-undang lain atau dengan keseluruhan sistem hukum. Dalam metode penafsiran ini, hukum dilihat sebagai satu kesatuan yang utuh, tidak merupakan bagian yang berdiri sendiri tetapi merupakan bagian dari satu sistem.

Dengan demikian ketentuan Pasal 101 ayat (1) yang hanya menyatakan barang bukti perkara narkotika dirampas untuk Negara oleh Hakim di Pengadilan Negeri Purbalingga dihubungkan dengan Pasal 45 ayat (4) KUHAP yang mengatur tentang barang sitaan yang bersifat terlarang atau dilarang diedarkan dinyatakan dirampas untuk dimusnahkan, sehingga menurut para narasumber penambahan frasa kata "dan untuk selanjutnya dimusnahkan" tidak bertentangan dengan Pasal 101 ayat (1) Undang-undang Nomor 35 tahun 2009 tentang Narkotika.

Penggunaan metode penafsiran sistematis yang dilakukan oleh Majelis Hakim di Pengadilan Negeri Purbalingga adalah suatu bentuk penyelesaian untuk mengatasi suatu aturan atau ketentuan yang menimbulkan permasalahan di dalam pelaksanaannya dimana memberikan kepastian hukum bagi Penuntut Umum terhadap status barang bukti narkotika tersebut. Dan apa yang dilakukan oleh Majelis Hakim di Pengadilan Negeri Purbalingga tidak menyimpang atau keluar dari sistem perundangundangan.
Jika ditinjau dari aspek penegakan hukum putusan hakim di Pengadilan Negeri Purbalingga di dalam perkara tindak pidana narkotika yang menyatakan barang bukti narkotika dinyatakan dirampas untuk Negara dan untuk selanjutnya dimusnahkan tidak bertentangan dengan Pasal 101 ayat (1) Undangundang Nomor 35 tahun 2009 tentang Nakotika karena telah mempertimbangkan aspek yang bersifat :

- Ada kekuatan yuridis (diatur di dalam Pasal 101 ayat (1) Undang-undang Nomor 35 tahun 2009 tentang Narkotika, Pasal 46 ayat (2) KUHAP),

- Ada kekuatan sosiologis (manfaatnya dari putusan),

- Ada kekuatan filosofis (adil untuk fungsi perlindungan masyarakat).

sehingga dengan mempertimbangkan ke-3 aspek tersebut keadilan yang ingin dicapai, diwujudkan, dan dipertanggungjawabkan dalam putusan hakim yang menyatakan barang bukti narkotika dirampas untuk Negara dan untuk selanjutnya dimusnahkan adalah keadilan yang berorientasi pada keadilan hukum (legal justice), keadilan moral (moral justice), dan keadilan masyarakat (social justice).

\section{Penutup}

Simpulan

Berdasarkan hasil penelitian dan pembahasan yang 
telah dilakukan oleh penulis, maka dapat diambil suatu simpulan, sebagai berikut :

1. Barang bukti narkotika adalah barang yang sifatnya terlarang dan berbahaya, perampasan terhadap barang bukti narkotika di dalam ketentuan Pasal 101 ayat (1) Undangundang Nomor 35 tahun 2009 tentang Narkotika adalah hal yang sudah tepat. Alasan atau dasar pemikiran terhadap perampasan barang bukti narkotika untuk Negara mempunyai alasan yuridis maupun alasan teknis atau praktis. Alasan yuridis karena diatur di dalam ketentuan Pasal 101 ayat (1) UndangUndang Nomor 35 tahun 2009 tentang Narkotika sedangkan alasan teknis atau praktis memberikan kemudahan bagi lembaga penelitian maupun industri farmasi untuk memperoleh narkotika.

2. Penambahan frasa kata "dan untuk selanjutnya dimusnahkan" oleh Hakim dalam memutus perkara tindak pidana narkotika di Pengadilan Negeri Purbalingga tidak bertentangan dengan Pasal 101 ayat (1) Undang-Undang Nomor 35 tahun 2009 tentang Narkotika, karena barang bukti narkotika adalah barang bukti yang sifatnya barang berbahaya, rawan untuk disalahgunakan, sehingga apa yang dilakukan oleh Majelis Hakim di Pengadilan Negeri Purbalingga dengan cara melakukan penafsiran sistematis yaitu menafsirkan peraturan perundangundangan dengan menghubungkannya dengan peraturan hukum atau undangundang lain atau dengan keseluruhan sistem hukum tidak menyimpang atau keluar dari sistem perundangundangan dan tentunya telah memberikan kepastian hukum bagi Penuntut Umum terhadap status barang bukti narkotika tersebut.

3. Putusan Hakim di Pengadilan Negeri Purbalingga yang menyatakan barang bukti narkotika dirampas untuk Negara dan untuk selanjutnya dimusnahkan tidak bertentangan dengan ketentuan Pasal 46 ayat (2) KUHAP sebagai aspek hukum acaranya dalam melakukan pemusnahan barang bukti narkotika dan sebagai alasan yuridis dalam melakukan perampasan barang bukti narkotika sudah sesuai dengan ketentuan di dalam Pasal 10 huruf $b$ KUHP dan Pasal 39 ayat (1) KUHP.

Saran. 
1. Pasal 101 ayat (1) Undangundang Nomor 35 tahun 2009 tentang Narkotika khususnya mengenai barang bukti narkotika kurang sempurna dalam pelaksanaannya tidak memberikan kepastian hukum bagi penuntut umum karena tidak adanya perintah untuk melakukan pemusnahan sehingga perlunya dilakukan revisi terhadap ketentuan Pasal 101 ayat (1) Undangundang Nomor 35 tahun 2009 tentang Narkotika agar di dalam pelaksanaannya tidak menimbulkan permasalahan kembali bagi Penuntut Umum.

2. Dalam Putusan Majelis Hakim Pengadilan Negeri Purbalingga yang menyatakan barang bukti narkotika dirampas untuk Negara dan untuk selanjutnya dimusnahkan harus dicantumkan sebagai alasan yuridis dalam melakukan pemusnahan barang bukti narkotika ketentutan Pasal 101 ayat (1) Undang-undang Nomor 35 tahun 2009 tentang Narkotika dihubungkan atau dijounctokan dengan ketentuan Pasal 46 ayat (2) KUHAP.

3. Pemerintah maupun Dewan Perwakilan Rakyat (DPR) sebagai lembaga pembentuk Undang-Undang setiap

\begin{tabular}{lrr} 
membuat & \multicolumn{2}{r}{ Undang-undang } \\
diharapkan memperhatikan & merikut: \\
hal-hal sebagai & berlana \\
pertama, diperlukan & adanya \\
kehati-hatian & dalam \\
merumuskan bunyi & suatu \\
kaidah. & Pengetahuan \\
sistematik dan & ketepatan \\
bahasa, baik Pemerintah \\
maupun
\end{tabular}
diperlukan, kedua, harus ada harmonisasi, yaitu memeriksa hubungan sistematik baik secara internal maupun dengan berbagai peraturan perundang-undangan lainnya, ketiga, secara lebih dini, setiap RUU disetai memori penjelasan yang komperehensif dan rinci, bukan sekedar penjelasan umum dan pasal demi pasal seperti praktek yang berlaku.

\section{Daftar Pustaka}

Ali, Zainuddin, 2014. Metode Penelitian Hukum, Sinar Grafika, Jakarta

Harahap, Yahya, 2005, Pembahasan Permasalahan dan Penerapan KUHAP, Sinar Grafika, Jakarta,

Kansil, C.S.T., 2002, Pengantar IImu Hukum, Balai Pustaka, Jakarta

Manan, Bagir, 2004, Hukum Positif Indonesia (Suatu Kajian Teoritik), FH UII Press, Yogyakarta

M. Hadjon, Philipus dan Tatiek Sri Djatmiati, 2014, Argumentasi Hukum, Gadjah Mada University Press, Yogyakarta

Mahmud Marzuki, Peter, 2005, Penelitian Hukum, Kencana Prenada Media Group, Jakarta

Mertokusumo, Soedikno, 2006, Penemuan Hukum suatu Pengantar,Liberty, Yogyakarta 
Mertokusumo, Soedikno, 2008, Mengenal Hukum, Liberty, Yogyakarta

Poerwadarminta, W.J.S., 2006, Kamus Umum Bahasa Indonesia, Balai Pustaka, Jakarta

Simorangkir, J.C.T, 2004, Kamus Hukum, Sinar Grafika, Jakarta

Soekanto, Soerjono dan Sri Mamudji,2012, Penelitian Hukum Normatif, Raja Grafindo Persada, Jakarta

Sunggono, Bambang, 2003. Metodologi Penelitian Hukum, Rajawali Press, Jakarta

Peraturan Perundang-undangan

Indonesia, Undang - undang Nomor 35 Tahun 2009 tentang Narkotika.

Undang - undang Nomor 8 Tahun 1981 tentang Hukum Acara Pidana dan Kitab Undangundang Hukum Pidana (KUHP). 